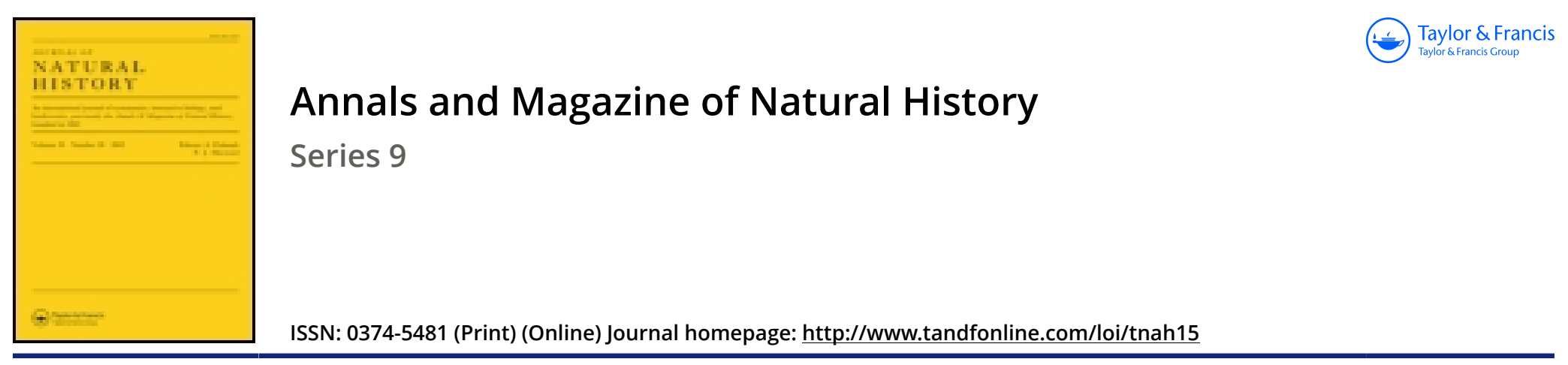

\title{
XLVIII._On Indo-Chinese hymenoptera collected by R. Vitalis de Salvaza.-II
}

\section{Rowland E. Turner F.Z.S. F.E.S.}

To cite this article: Rowland E. Turner F.Z.S. F.E.S. (1919) XLVIII._On Indo-Chinese

hymenoptera collected by R. Vitalis de Salvaza._-II, Annals and Magazine of Natural History, 3:17, 483-487, DOI: $10.1080 / 00222931908673847$

To link to this article: http://dx.doi.org/10.1080/00222931908673847

\section{Published online: 02 Sep 2009.}

Submit your article to this journal ¿

Џ Article views: 3

Q View related articles ¿

Citing articles: 2 View citing articles $\square$ 
dilated joints, clothed beneath with a few whitish scales; first joint of hind tarsi nearly equalling the succeeding three joints. Claws simple, but with faint traces of denticulation at base.

The generic name means in Sanskrit a "swollen neck."

The type of the genus is Thyreopterus impressus, Schm. Goeb. Faun. Col. Birm. 1846, p. 80. This is the only Oriental species described under the genus Thyreopterus, and its generic characters do not accord with those of the African species of that genus.

CALLIDINI.

Crossoglossa, Chaud. Mon. des Callidides, Ann. Soc. Ent. Belg. xv. 1872, p. 177= Phlocodromius, W. Macleay, Tians. Ent. Soc. N.S.W. ii. 1871, p. 85 .

$\mathrm{Mr}$. T. G. Sloane pointed out to me the identity of these two genera, but I do not think he has published any note on it.

Saronychium inconspicuum, Blackb. Kint. Month. Mag. xiv. 1877, p. 142=Endynomena pradieri, Fairm. Rev. et Mag. Zool. 1849, p. 34 .

L E B I I N I.

Cymindis pictula, Bates, Trans. Ent. Soc. Lond. 1873, p. 310 = Anomotarus (Cymindis) stigmula, Chaud. Bull. Mose. 1852 , i. p. 57.

The genus Uvea was proposed by Fauvel (Bull. Soc. Ent. Fr. 1881, p. 118 ; id. Rev. d'Ent. i. 1882 , p. 257) for Chaudoir's species, but Mr. T. G. Sloane, Proc. Linu. Soc. N.S.W. 1917, pp. 435-6, does not consider it as "more than, at most, a subgenus of Anomotarus."

XLVIII.-On Indo-Chinese Hymeneptera collected by $R$. Vitalis de Salvaza.-II. By Rowland E. 'I'URner, F.Z.S., F.E.S.

\section{Family Tenthredinidæ.}

Subfamily ARGINA.

Arge vitalisi, sp. $\mathrm{n}$.

ㅇ. Lutea; mandibulis apice nigris; mesopleuris, tergitis $1-3$ macula transversa mediana, quarto fere toto, 5-7 fascia lata 
mediana, oetavo macula magna mediana, sternito quarto macula. laterali utrinque, coxis posticis, apice excepto, femoribusque posticis, basi luteis, nigro-purpureis ; alis flavo-hyalinis, stigmate venisque nigris, sub stigmate late transverse brunneofasciatis.

Long. $13 \mathrm{~mm}$.

. Head not narrowed behind the eyes ; clypeus and face finely punctured; a carina running downward from the base of each antenna, the two joining about halfway botween the antennæ and the base of the clypeus and enclosing a raised elongate-ovate area, from the apex of which a low carina runs to the base of the clypeus. Antennz as long as the head and thorax combined; the third joint long, compressed and broadened towards the apex. Front above the antenna with a deep longitudinal groove; vertex very finely and rather sparsely punctured. Vertical area slightly convex, nearly three times as broad as long, not sharply defined laterally. Thorax smooth and shining; the mesonotum anteriorly minutely and rather sparsely punctured. The space between the basal nervure and the origin of the cubitus is scarcely as long as the intercostal nervure; the nervulus is received at about two-fifths from the base of the discoidal cell. Hind tibiæ with spine.

Hab. Ban Thiou, Luang Prabang; March 18, 1918. 1 q .

This fine species is very distinct in colour from unost species of the genus, but does not differ structurally or in neuration.

Subfamily TENTHREDININE.

Conaspidia fasciatipennis, sp. n.

9. Ochracea, nitida; mandibulis apice, vertice maculis tribus magnis, mesonoto antice lateribusque, tergitis tertio sequentibursque, tibiis apice extremo, femoribusque posticis linea supra, nigris; alis hyalinis, vix flavo-suffusis, anticis sub stigmate late fusco-fasciatis, apice in cellula cubitali quarta infuscatis, stigmate venisque fuscis, costa ochracea.

Long. $11 \mathrm{~mm}$.

7. Clypens widely and rather deeply emarginate, rugosely punctured. Eyes separated from the base of the mandibles by a distance not exceeding one-third of the length of the second antennal joint. Antennæ as long as the abdomen, filiform, the third joint nearly four times as long as the second, the joints beyond the third gradually decreasing in length. Fiont finely rugose; vertex shining, shallowly and 
sparsely punctured, vertical area longer than its greatest breadth, slightly narrowed anteriorly; the head swollen behind the eyes. Mesonotum obsoletely punctured, the median lobe divided from base to apex by a deep groove in which lies a low carina. Scutellum coarsely punctured, raised into a conical tuberele; mesopleuræ coarsoly rugulose. Abdomen smooth. The apical fuscous mark on the fore wing is paler than the median fascia and occupies almost the whole of the fourth cubital cell and the extreme apex of the radial cell. The median fascia crosses the wing from the basal half of the stigma and does not extend apically beyond the second transverse cubital nervure. The discoidal nervure is separated thom the base of the cubital nervure by a distance about equal to the length of the first transverse cubital nervure.

Hab. Tong Lap, Haut Mékong; April 30, 1918. $1 q$.

Differs very strongly in colour from $C$. sikhimensis, Konow, the only other known species of the genus, especially in the fasciate wings; but the neuration and structure do not differ appreciably.

\section{Macrophya extrema, sp. n.}

ㅇ․ Nigra; clypeo, labro, mandibulis basi, antennis articulis tertio quartoque intus, pronoto, tegulis basi, mesopleuris fascia lata mediana, scutello macula magna, cenchris, metanoto linea angusta apicali utrinque, propodeo fascia apicali lateribus fortiter dilatata, tergito apicali, coxis posticis supra, trochanteribus, femoribus anticis intermediisque, supra nigro-lineatis, femoribus posticis, apice nigris, tibiis basi, tarsisque, unguiculis exceptis, alboflavidulis; alis fusco-hyalinis, basi fere hyalinis, stigmate venisque nigris.

d. Feminæ similis.

Long., 우 11-13, o $11 \mathrm{~mm}$.

‥ Clypeus convex, very widely and shallowly emarginate, strongly punctured. Front very closely punctured-rugulose, vertex more coarsely and sparsely punctured, the front clothed with short white pubescence; vertical area puncturedrugulose, a little broader posterionly than long, strougly narrowed anteriorly, the oblique lateral grooves swooth and shining. Antennæ with joints 5-7 thickened and somewhat compressed, the third joint as long as the fourth and fifth combined. Thorax closely punctured, the middle lobe of the mesonotum much more coarsely punctured than the lateral lobes and divided by a longitudiual groove nearly reaching the apex; mesopleuræ very coursely punctured. in front, Ann. \& Mag. N. Hist. Ser. 9. Vol. iii. 
rugulose posteriorly. Abdomen smooth and shining, propodeum rather closely punctured; hind coxæ, femora, and tibia closely punctured. Humeral cell divided far before the middle by a very short nervure.

Hab. Vien Poukha, Haut Mékong; May 11, 1918. 1 , $3 \delta$ o.

Somewhat related to the European M. rustica, Linn., but the antennæe are much longer than in that species, the clypeus less strongly emarginate, the puncturation coarser, and the humeral cell more contracted.

\section{Family Ichneumonidæ.}

Subfamily $C_{R Y P T I N Z \text {. }}$

Mansa funerea, sp. n.

१. Nigra; antennis dimidio basali, palpis, abdominis segmento tertio sequentibusque, valvulis terebræ, pedibusque, coxis exceptis, fulvo-ferrugineis; mandibulis basi, oculorum orbitis internis late, abdominisque segmento secundo fusco-ferrugineis; alis fuscis, venis nigris.

Long. $16 \mathrm{~mm}$, t terebræ long. $6 \mathrm{~mm}$.

\%. Head strongly narrowed behind the eyes and towards the clypeus; cheeks long, about equal in length to the fourth antennal joint. Mandibles narrowed to the apex, ending in two very small teeth. Clypeus broadly truncate at the apex, closely and minutely punctured and clothed with fuscous hairs ; face coarsely punctured-rugose. Antennæ inserted nearly as far from the anterior ocellus as from the apex of the clypeus, 39-jointed, scape produced beneath so as to form a partial sheath for the second joint; the third joint the longest, the fourteen basal joints fulvo-ferruginous, the antenne gradually thickened to about the twentieth joint. Front and vertex finely rugulose, the space above the base of the antennæ smooth and shining and feebly concave. Thorax opaque, very closely and rather strongly punctured; the pleuræ rugosely punctured, with a broad oblique band on the middle of the mesopleuræ smooth and shining. Median segment coarsely punctured-rugose; the spiracles large and elongate, enclosed in an elongate triangular lateral area; on each side of the dorsal surface of the segment at the base is an area enclosed by the upper side of the lateral area, the base of the segment, and a curved caina which reaches the base a little on the outer side of the middle. Abdomen rather indistinctly microscopically punctured; first segment petiolate, the spiracles nearer to the apex of the segment than 
to each other; the apical quarter of the segment rather strongly broadened, the whole segment as long as the hind coxa and trochanters combined. Areolet very large, about half as long again on the radius as on the cubitus, the second abscissa of the radius fully as long as the first and very little shorter than the third. Second recurrent nervure received just beyond one quarter from the base of the second cubital cell.

Hab. Vieng Vai, Haut Mékong; June 10, 1918. 1 q.

Easily distinguished by the dark fuscous wings from all other known Oriental species of the genus. The name Mansa, Tosq. (1896), has priority over Colganta, Cam. (1902), which must sink as a synonym.

\section{Family Braconidæ.}

Subfamily HaLCONIN.X.

Helcon unicornis, Tarn.

Helcon unicornis, Turn. Ann. \& Mag. Nat. Hist. (9) ii. p. 172 (1918). 오.

Hab. Tong Lap, Haut Mékong; April 30, 1918.

This species seems to resemble closely Wroughtonia cornuta, Cam., placed by that author among the Evaniidr, and I think it quite possible that my name may have to sink as a synonym. Cameron's description is not very clear, and was taken from a specimen with broken antennæ. But, on the whole, I think there can be no doubt that the genus Wroughtonia belongs here, and should sink as a synonym.

XLIX.-Description of a new Genus and Two new Species of Heterocera. By Lord RoTHSCHILD, F.R.S.

Spilosoma ignivagans, sp. n.

ठ. Very closely allied to erythrophleps, Hmpsn., but with less red on fore wings and fewer pale markings on hind wings.

Antennæ black, pectus and legs sooty-slate, frons and vertex rufous-orange; thorax rufous-orange, with a sooty dot on tegulæ and sooty streaks on patagia; abdomen abovo rufous-orange ringed with sooty black, bolow white.

Fore wing slate-brown with orange-scarlet nervures; three ill-defined orange-scarlet patches on basal half of costa; two rufous-orange spots in cell and one beyond; four irregular $32 *$ 